\title{
Developments in breeding cereals for organic agriculture
}

\author{
M. S. Wolfe $\cdot$ J. P. Baresel · D. Desclaux $\cdot$ I. Goldringer \\ S. Hoad · G. Kovacs · F. Löschenberger · T. Miedaner • \\ H. Østergård · E. T. Lammerts van Bueren
}

Received: 13 December 2007/Accepted: 8 April 2008/Published online: 27 May 2008

(C) The Author(s) 2008

\begin{abstract}
The need for increased sustainability of performance in cereal varieties, particularly in organic agriculture (OA), is limited by the lack of varieties adapted to organic conditions. Here, the needs for breeding are reviewed in the context of three major marketing types, global, regional, local, in European OA. Currently, the effort is determined, partly, by the outcomes from trials that compare varieties under OA and CA (conventional agriculture) conditions. The differences are sufficiently large and important to warrant an increase in appropriate breeding. The wide
\end{abstract}

M. S. Wolfe $(\square)$

The Organic Research Centre, Wakelyns Agroforestry, Fressingfield, Eye, IP21 5SD Suffolk, UK

e-mail: wolfe@wakelyns.demon.co.uk

\section{J. P. Baresel}

Technical University, München-Weihenstephan, Alte Akademie 16, 85354 Freising, Germany

D. Desclaux

INRA, UMR 1097, F-34060 Montpellier, France

I. Goldringer

INRA, UMR de Génétique Végétale, INRA UPS INA-PG

CNRS, Ferme du Moulon, 91190 Gif sur Yvette, France

S. Hoad

Scottish Agricultural College, West Mains Road, EH9

3JG Edinburgh, Scotland, UK

G. Kovacs

Agricultural Research Institute of the Hungarian Academy of Sciences, Brunszvik u. 2, Martonvasar, Hungary range of environments within $\mathrm{OA}$ and between years, underlines the need to try to select for specific adaptation in target environments. The difficulty of doing so can be helped by decentralised breeding with farmer participation and the use of crops buffered by variety mixtures or populations. Varieties for OA need efficient nutrient uptake and use and weed competition. These and other characters need to be considered in relation to the OA cropping system over the whole rotation. Positive interactions are needed, such as early crop vigour for nutrient uptake, weed

\author{
F. Löschenberger \\ Saatzucht Donau GesmbH \& CoKG, Saatzuchtstraße 11, \\ 2301 Probstdorf, Austria \\ T. Miedaner \\ University of Hohenheim, Landessaatzuchtanstalt, State \\ Plant Breeding Institute, Fruwirthstr. 21, 70593 Stuttgart, \\ Germany \\ H. Østergård \\ Ris $\varnothing$ National Laboratory DTU, Biosystems Department, \\ P.O. Box 49, 4000 Roskilde, Denmark \\ E. T. Lammerts van Bueren \\ Wageningen UR Plant Breeding, Wageningen University, \\ P.O. Box 386, 6700 AJ Wageningen, The Netherlands
}


competition and disease resistance. Incorporation of all characteristics into the crop can be helped by diversification within the crop, allowing complementation and compensation among plants. Although the problems of breeding cereals for organic farming systems are large, there is encouraging progress. This lies in applications of ecology to organic crop production, innovations in plant sciences, and the realisation that such progress is central to both $\mathrm{OA}$ and $\mathrm{CA}$, because of climate change and the increasing costs of fossil fuels.

Keywords Direct and indirect selection . Variety testing - Participatory plant breeding . Wide and specific adaptation - Crop diversity . Organic agriculture

\begin{tabular}{|c|c|}
\hline \multicolumn{2}{|c|}{ Abbreviations } \\
\hline ABDP & $\begin{array}{l}\text { Association of Biodynamic Plant } \\
\text { Breeders }\end{array}$ \\
\hline $\mathrm{AM}$ & Arbuscular Mycorrhizae \\
\hline BFCA & $\begin{array}{l}\text { Breeding programmes For Conventional } \\
\text { Agriculture }\end{array}$ \\
\hline BFOA & $\begin{array}{l}\text { Breeding programmes For Organic } \\
\text { Agriculture }\end{array}$ \\
\hline $\mathrm{CA}$ & Conventional Agriculture \\
\hline DON & Deoxynivalenol \\
\hline DUS & Distinctness, Uniformity and Stability \\
\hline FHB & Fusarium Head Blight \\
\hline GEI & Genotype $\times$ Environment Interaction \\
\hline GMO & Genetically Modified Organism \\
\hline GxL & Genotype by Location interaction \\
\hline HMWGS & $\begin{array}{l}\text { High Molecular Weight Glutenin } \\
\text { Sub-units }\end{array}$ \\
\hline HY & High Yielding \\
\hline IFOAM & $\begin{array}{l}\text { International Federation of Organic } \\
\text { Agriculture Movements }\end{array}$ \\
\hline IPR & Intellectual Property Rights \\
\hline LY & Low Yielding \\
\hline MAS & Marker-Assisted Selection \\
\hline NUUE & Nutrient Uptake and Use Efficiency \\
\hline $\mathrm{OA}$ & Organic Agriculture \\
\hline OPB & $\begin{array}{l}\text { Organic Plant Breeding (programmes } \\
\text { within OA) }\end{array}$ \\
\hline PBR & Plant Breeders Rights \\
\hline PPB & Participatory Plant Breeding \\
\hline QTL & Quantitative Trait Loci \\
\hline
\end{tabular}

TKW Thousand Kernel Weight

VCU Value for Cultivation or Use

\section{Cereal breeding: needs for organic production}

The rapid development of conventional agriculture (CA) over the last 60 years, exemplified by a massive increase in cereal grain production, has been dependent upon a large and continuous investment in plant breeding. Across Europe, breeders have produced hundreds of pedigree line varieties during this time, all adapted to production within $\mathrm{CA}$, and often successful, individually, over relatively large areas. Such performance has been dependent on large-scale, fossil fuel-based inputs that have helped to limit environmental variability. However, climate change coupled with rising oil prices is now beginning to affect developments in conventional breeding.

Over this same time period, organic agriculture (OA) has developed much more slowly, hindered by a lack of breeding investment on the one hand, and by the problems of coping with much greater environmental variability on the other. However, the greater dependence of OA on ecological rather than chemical approaches is opening up many different and novel ways, potentially, of dealing with both increasing variability related to climate change, and the costs of fossil fuel-based control of the environment.

$\mathrm{OA}$ relies on measures that stimulate the resilience and self-regulating ability of the farming system, e.g. by enhancing biodiversity (at the farm, crop and genetic level) and soil fertility with a high level of organic matter and wide crop rotation, and by closing the nutrient cycle as much as possible (e.g. Mäder et al. 2002). This approach implies that all parts of the agricultural system including food, water and energy, are regarded as a whole and interactions and feedback among all parts are considered in optimising that whole. The holistic approach attempts to maintain the integrity of all living entities, such as soil, plants, animals, farm, landscape and ecosystem (Verhoog et al. 2003). However, because there are fewer opportunities for immediate compensation or alleviation of abiotic and biotic stress in OA compared to $\mathrm{CA}$, the need for adaptation of varieties to varied environmental conditions is currently more 
important in OA. Furthermore, because organic farming systems are necessarily adapted to their localities, there is a wide diversity among them, and indeed among individual farms. This requires therefore, a fine-grained adaptation of the crop plants (and animals) used on individual farms. It is also important to consider the relationship between the actual crop, its pre- and post-crop and the overall contribution and impact of the actual crop on the whole rotation, including the livestock element. This need to consider choice of cereal species and variety in the context of the whole farming system should also have an impact on the breeding approach.

These needs for OA cannot be achieved easily by centralised breeding. Although OA is well established in most European countries, breeding specifically for organic farming systems has received little attention. In this paper, we argue that there is a need for different approaches to plant breeding to improve organic farming systems and organic product quality relative to current conventional practice and that this will differ for different markets. We concentrate on cereals, particularly wheat, because it is the most important single crop among, currently, nearly 900,000 ha of organic cereals in Europe. Organic cereals are not only important for feed and food, but also for their contribution to good soil structure and soil fertility in a sound organic farming system. Cereals also deliver straw as a vital component for organic animal housing systems and for composting farmyard manure.

Within this context, we outline the current structure of OA in Europe and the current status of cereal breeding for OA. This leads on to a consideration of appropriate breeding strategies and the characteristics required within those strategies. A brief discussion of breeding techniques is followed by some final comments on the future of cereal breeding for OA.

\section{Organic agriculture defined by three market types that need different solutions}

In detail, it is likely that there are almost as many organic farming systems as there are organic farmers. This arises because of the problems that individuals face in adapting the framework of organic farming (Council Regulation (EC) 2007, No 834/2007) to the environmental variables of an individual farm. In this sense, the ideal breeding approach would be a specific programme for each farm. However, to simplify this view, we need to use broader categories, among which the following, based on the market approach for each farm, is helpful for this review (Table 1):

- Global commodity farming, by larger scale farms and farm associations which produce either feed under relatively low-input conditions, or grain for industrialized bakeries requiring high levels of protein for standardized baking procedures. Modern cereal varieties, with relatively high levels of nitrogen input are used to meet the homogeneity and the specific quality standards combined with high productivity. The farm objectives are predominantly oriented to large markets.

- Regional market farming, on both large and small-scale farms, allowing a more variable product, using both modern and older or regional varieties. The farm objectives here are largely ecological, with a major emphasis on minimising inputs.

- Local market farming, mainly by small-scale farmers on mixed farms who regard the crop, farm landscape and society as a whole; they are more likely to use local or conservation varieties. The grain is produced for artisanal bakeries prepared to adjust their baking process according to the variation in flour quality. The farmer's objectives are more social.

In the Table, the kinds of breeding strategy and their application to the three generalised forms of OA relate to the three approaches to naturalness described by Verhoog et al. (2003), see also Lammerts van Bueren and Struik (2004). The scheme indicates a progression based on the form of selection, moving from 'natural' selection in populations (no intervention), to farmer participation (mass selection for specific characters or for site), to farmer plus breeder, to breeder alone. We would expect this progression to be associated with a progression from the local market to the global market production system, although this might easily be upset by unusual success, or failure, at a particular point in the progression. In practice, a wide range of combinations exists and should be promoted in order to enhance interactions among all players. Promoting diversity and increasing the number of breeders will enhance the diversity of genetic material. 


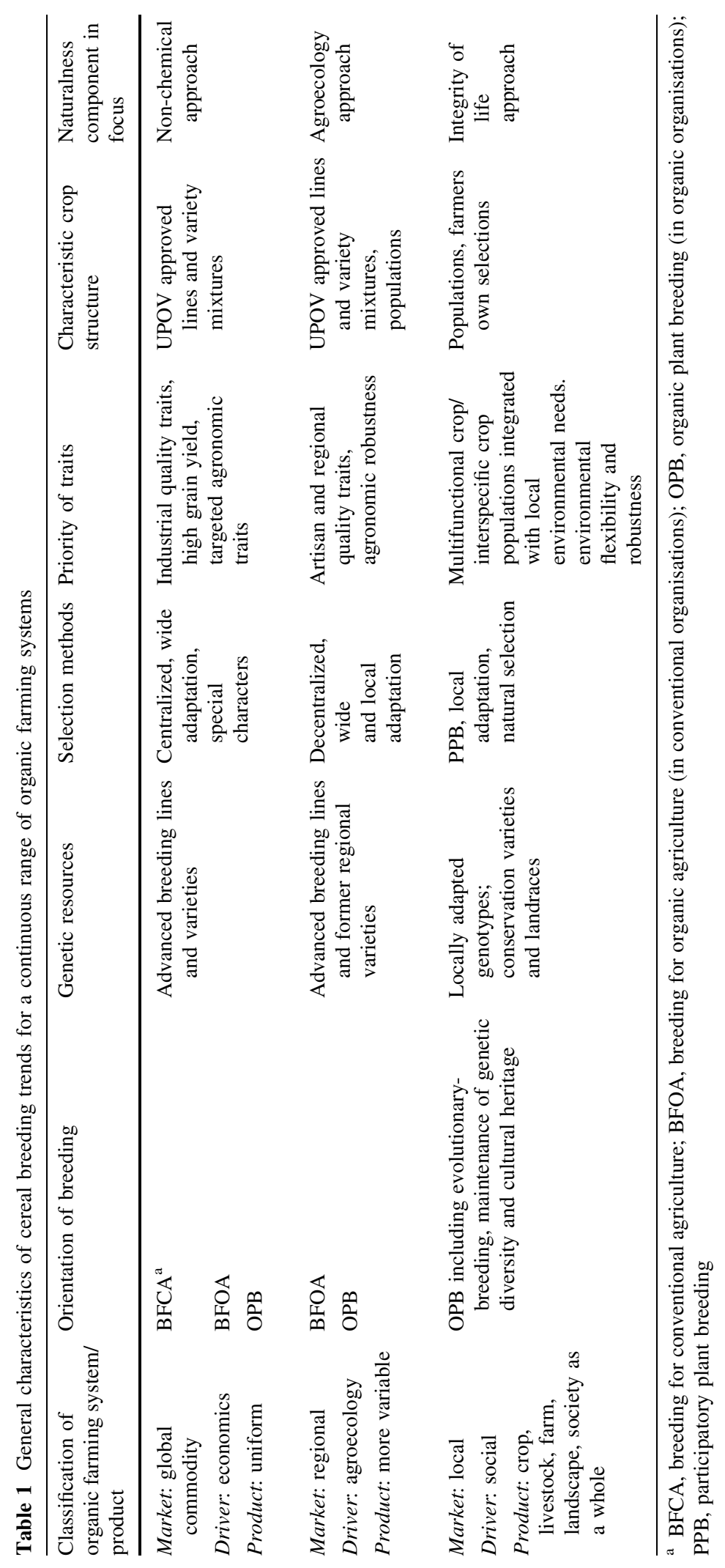


A large number of cereal varieties is available across Europe from conventional breeding programmes, some of which will fulfil partly the requirements of OA. However, better adapted varieties are needed to optimise OA systems and to comply with the required product quality under lowinput, OA conditions, particularly for regional and local marketing (Rastoin 2006). The traits required reflect the fundamental differences between OA and $\mathrm{CA}$ in the management of soil fertility, weeds, diseases and pests, together with the different demands on product quality and yield stability under organic conditions (Lammerts van Bueren et al. 2002).

\section{Current status of cereal breeding for organic agriculture}

Currently, most organic farmers depend on modern varieties bred for conventional agricultural systems. However, because of the European Organic Seed Regulation (EC 1452/2003), the use of organic seeds is becoming compulsory. Overall, the varieties used in OA originate from three different sources:

(1) Breeding programmes for conventional agriculture (BFCA). Organic farmers select from among the currently available varieties those that perform well enough under organic conditions. BFCA is common in the global marketing model (Table 1).

(2) Breeding programmes for organic agriculture (BFOA). Such breeding programmes often start with specific crosses for OA, but for economic reasons, selection in the first generations (F1F5) is conducted under regular (conventionally managed) conditions. In later stages of the breeding process, promising lines are tested under organically managed conditions. BFOA is useful across all three organic farming models.

(3) Breeding programmes within organic agriculture (OPB), which means that all breeding steps are executed under organic conditions with selection and propagation techniques that comply with organic principles. These programmes cover a range from breeder-driven to farmerdriven activities. Among the farmers there are those who use their own selections originating from older (regional) varieties or landraces. OPB may be most applicable in the local market model of OA, but also for regional markets.

BFOA takes advantage of the fact that, under specified environmental conditions, the expression of several traits can be highly correlated between CA and OA (Oberforster et al. 2000; Oberforster 2006; Przystalski et al. 2008). This holds true for yield where CA is practised at low-input levels, e.g. with limited nitrogen supply and without the application of fungicides. For highly heritable traits where selection can be imposed in the early stages on a single plant or small plot basis, indirect selection, i.e. selection in an environment different from the target environment, can even lead to higher selection efficiency than direct selection (Hill et al. 1998). Examples for highly heritable traits in wheat in some conditions are: tillering capacity, early vigorous growth, earliness (heading date), disease resistance, culm length, spike-length, other morphological characteristics and grain features such as thousand kernel weight (TKW). A few varieties have already been released from BFOA programmes including Naturastar in Germany (Kempf 2002) and several varieties in Austria (Bundesamt für Ernährungssicherheit 2007; Löschenberger et al. 2008).

The selection strategies for low-input conditions imposed by Hänsel and Fleck (1990) and Spanakakis and Röbbelen (1990) have led to varieties adapted to OA in several European countries together with new conventional varieties that perform best in $\mathrm{OA}$ in the US (Carr et al. 2006).

OPB uses exclusively organic conditions and can be referred to as direct selection (see Murphy et al. 2007). Major differences from the CA environment are the limited level and less controlled nitrogen availability to the plant, weed competition, less pressure from several diseases (e.g. powdery mildew, Septoria tritici in wheat), but additional diseases (e.g. bunts and smuts). Furthermore, the relative importance of specific traits differs between CA and OA (yield and quality). There is a small number of breeders who are conducting OPB programmes for cereals, mainly in Switzerland, Germany and Hungary. For example, ABDP (Association of Biodynamic Plant Breeders) are developing lowinput cereal varieties for organic farming with more regional adaptation. Some 12 varieties have been 
registered by them (Kunz 2007; Bundessortenamt 2007; Bedő and Kovács 2006) The advantages of these varieties are most pronounced in environments with low N availability (Heyden 2004). Such varieties are mostly taller and have lower harvest indices and higher grain protein content than varieties from BFCA programmes.

New genetic material from other farming systems has to be introduced continuously into OA in order not to lose genetic variability (Carr et al. 2006). The highest possible variability of varieties for OA can be assured by extending the choice to varieties developed within all three breeding strategies, BFCA, BFOA and OPB. After sound testing under organic conditions, organic farmers can then choose either specifically or widely adapted varieties for particular situations. Considering the current multiplication acreage of organic seed in Europe as a reflection of farmer's demand, we can conclude that modern rather than old varieties are the best choice currently for production in OA. Furthermore, the development costs of any variety for the market requires a minimum quantity of seed production, which implies that widely adapted varieties are more likely to be successful.

\section{Breeding strategies for organic cereal varieties and crops}

The diversity of agro-ecological and climatic conditions together with different cultural practices in OA represent a considerable challenge for breeders (Murphy et al. 2005). Breeding for OA needs specific strategies that utilise genetic diversity to support or enhance the wide-ranging conditions and farmer practices. These aspects have seldom been investigated in the context of breeding cereals for OA in Europe, but some lessons can be drawn from experiments in various low-input/stressed compared to conventional/non stressed environments.

Breeding for OA must be considered in the context of whole system management, through rotation and other agronomic practices, that can help to buffer the system and its components against abiotic and biotic variability and stress. In this sense, selection of crops for use in OA should be driven by the needs of the whole system as well as the end use. For example, crop nutrition and weed competition can both be helped by the structure of the rotation together with appropriate agronomic interventions. Crop varieties should then be selected according to different priorities in the farming system. Difficult challenges will no doubt arise because of interactions or trade-offs between different selection criteria. For example, a narrow approach focused on weed control may be disadvantageous if it neglected other important criteria such as disease control. A more holistic approach in which there is integration of different system components, perhaps including selective competition among the plant components, is highly desirable.

Diversity is the basis of natural selection and evolution and was the norm in agriculture until the last hundred years or so when modern genetics and plant breeding enabled farmers and end-users to exploit the benefits of uniformity. However, biological sciences continue to reveal the multiple advantages of diversity in all aspects of agricultural production. For example; the work of Tilman's group in the USA illustrates the basic principles for natural systems that are highly relevant to agricultural systems (Tilman et al. 2006). Other reviews include Finckh and Wolfe (2006). Most important is the need for recognition of the urgency and importance of new approaches to breeding based on using diversity - and that space has to be made for these within the current regulatory frameworks.

Considering these and other aspects, we recognise a number of key questions for the development of strategies appropriate to breeding for organic agriculture:

(1) Which genetic resources are appropriate?

(2) Should genotypes be selected for wide or specific adaptation?

(3) Stability of performance over time?

(4) What are the most suitable selection environments?

(5) Can decentralised approaches add to centralised breeding?

(6) Can participatory approaches add to centralised breeding?

(7) What is the most appropriate crop structure?

A further major question, on determining the selection criteria to be used, is dealt with in the following main section. 
Genetic resources

In addition to the resources available from modern agriculture, there is a need to identify appropriate genetic resources among the older varieties or landraces either for direct use or as potential parental lines in breeding programmes for better adapted varieties (Hoisington et al. 1999; Hammer and Gladis 2001; Lammerts van Bueren et al. 2005b). Evaluating and exploiting accessions from genebanks can be of use because characteristics required for organic, lowinput farming might have disappeared by selection under modern, high-input conditions, such as lowinput tolerance and deep or intensive root architecture. Many non-profit organisations dealing with in situ conservation of genetic resources maintain their populations under organic conditions (Negri et al. 2000).

However, despite the availability of large amounts of genetic resources, their real use in organic farming is still limited. More than 140,000 wheat accessions are held in the major genebanks including 95,000 maintained in Europe alone (Faberova and Le Blanc 1996). This includes populations, landraces or local cultivars, varieties and wild relatives, but only $1-2 \%$ are used in farming practice overall.

Although the importance and utilization of plant genetic resources is underlined in all strategic papers related to OA, it is difficult to find research related to their practical use, much as in conventional agricultural production and plant breeding. One of the major reasons is the difficulty in evaluating genebank accessions with widely differing phenotypes such as flowering dates, heights and growth morphologies, and quality features. The other main factor is the loss of locally adapted traditional genotypes or landraces, and that most of the ex situ conserved material is not adapted to modern farming conditions. These differences make accurate assessments and comparisons difficult, if not impossible. Even if useful characteristics can be identified, the difficulty of transferring the characteristics to a cultivated species, and the time involved, are considerable. For genetic resources to be a major factor in plant improvement, new methods must be directed to their analysis and transfer into improved varieties. These include physiological measures of plant parameters which are now becoming more exact, rapid, and applicable to large populations, as well as molecular markers (see below). Such advances should allow the more accurate determination of new sources of useful characteristics, or, may, indeed, result in new varieties for organic farming.

The situation is different with old varieties and under-utilised species (Padulosi et al. 2002). Several old varieties have been reintroduced into (organic) breeding and farming practice, and several underutilized species are succeeding as speciality crops in different regions in Europe. The cultivation of spelt, emmer and einkorn is increasing together with production of, for example, hull-less barley, naked oats and some other "curiosities" (Grausgruber and Arndorfer 2002; Kovács and Szabó 2006; Veisz 2006; Láng 2006). Such developments will be helped further by appropriate pre-breeding of relevant species and their inter-crosses.

Wide or specific adaptation

Target environments can be sub-divided into homogeneous subregions in which genotype by location (GxL) interactions are minimized and within-subregions genetic variances are increased (Comstock and Moll 1963; Ceccarelli 1989; Atlin et al. 2000a). However, the dilemma is that selecting the best genotype over the undivided region may or may not be more efficient than selecting the different genotypes which are best adapted to each subregion. Furthermore, the approach to selection should be considered in relation to the global, regional and local market categories noted above and corresponding to the commercialisation of varieties from widely to specifically adapted.

Atlin et al. (2000b) considered the effect of subdividing environments into sub-regions for the breeding of (sub-)regionally adapted varieties. They showed that subdivision will increase the response to selection only if GxL is large relative to the genetic variance and if a substantial $(>30 \%)$ part of GxL is due to genotype $\times$ sub-region interaction. The efficiency will also depend on the ability to define highly appropriate and meaningful subregions which was not systematically the case in the previous studies. A thorough study of GxL interaction over many environments and many years is necessary to obtain efficient subregions definition as illustrated for sunflower on-farm testing (de la Vega et al. 2001; de la Vega and Chapman 2006). 
Genotype $\times$ subregion interaction depends on the range of both genetic and environmental variation under study. Increasing the range of environments to severe stress conditions is more likely to result in GxL having a major contribution in the observed variation (Ceccarelli 1989). Reviewing a large set of cereal literature that supports the claim for selection of widely adapted genotypes, Ceccarelli indicated that widely adapted genotypes are the best performers in only a narrow range of environments and usually not including severe stresses. To adapt these results to breeding for OA, it is necessary to identify the range of targeted environments and to carry out experiments in different OA environments assessing heritability, genetic correlations across environments and the different variance components. Moreover, it might be more appropriate to define the sub-regions including farming practices such as livestock on farm or not. It is also important to recognise that climate change is likely to extend environmental variation, increasing the need for adaptation.

\section{Stability over time}

Because varieties in OA should have a broad range of adaptability to cope with a large variability in environmental conditions, they need to have various 'buffering capacities' to maintain performance. This means that varieties for OA must not have any severe local weakness in any trait relevant for growth and productivity. Increase and stability of productivity of a wheat variety depend on its individual buffering. In fact, wheat has a high degree of buffering capacity within the genotype (Udall and Wendel 2006), because of its allohexaploid genome, and this can be selected for. There is also likely to be variability among characters that have no detectable effect on features associated with DUS criteria (Distinctness, Uniformity, Stability), VCU (Value for Cultivation and Use) or other easily observable characters. These could also contribute to the buffering capacity of a variety over space and time. There is no doubt, however, that a deliberate approach to introducing genetic variation into the crop (see 'crop structure' below) will have greater value in this direction.

Under CA, individual buffering can also be seen as the varieties' ability to exploit favourable conditions in the environment (Tarakanovas and Ruzgas 2006). Spanakakis and Röbbelen (1990) proposed, therefore, the selection of "combination type" varieties. These varieties are able to react flexibly by adjusting their yield components to the environment, for example, through a high tillering capacity, variable numbers of grains per ear and high grain weight. Also Le Gouis et al. (2000) and Saulescu et al. (2005) proposed simultaneous selection under diverse input regimes in order to favour varieties for low-input management systems. Alternating selection between high and low yielding environments was the most effective way to develop wheat germplasm adapted to environments where intermittent drought occurs (Kirigwi et al. 2004).

Choice of selection environments: organic versus conventional

To develop varieties better adapted for organic farming systems, an important question is the choice of selection environment for organic plant breeding programmes, but little research has been done on this issue. As described above, plant breeders have developed different strategies (Hill et al. 1998), such as choosing an environment with optimal conditions for the crop or choosing the target environment (e.g. an organic environment or a stressed environment) for the crop, or even an alternation of these two. However, it still remains unclear whether the differences between conventional and organic growing systems are large enough to justify, economically, breeding and official variety testing in both environments, rather than the simpler inclusion of additional characteristics of relevance only for organic farming into conventional breeding and tests.

From a theoretical basis, Falconer (1952) established, more than 50 years ago, that direct selection, i.e. in the target environment, is almost always more efficient than indirect selection.

The theoretical framework of quantitative genetics (e.g. Falconer and MacKay 1996) can provide guidelines to optimise the selection strategy. Thereafter, the selection response from indirect selection (e.g. in conventional conditions) can be compared with direct selection (e.g. organic conditions). The relative efficiency of indirect selection is then:

$\mathrm{RE}=\frac{\mathrm{CR}}{\mathrm{DR}}=r_{\mathrm{A}(\mathrm{X}, \mathrm{Y})} \frac{h_{\mathrm{Y}}}{h_{\mathrm{X}}}$

with $\mathrm{CR}$, the correlated response on a given trait in environment $\mathrm{X}$ resulting from selection of the same 
trait in environment $\mathrm{Y}$, DR the direct response in environment $\mathrm{X}, r_{\mathrm{A}(\mathrm{X}, \mathrm{Y})}$, the additive genetic correlation between environments $\mathrm{X}$ and $\mathrm{Y}$ and $h_{\mathrm{X}}$ (resp. $h_{\mathrm{Y}}$ ) the narrow sense heritability in environment $X$ (resp. environment Y). Using this approach, Murphy et al. (2007) evaluated 35 winter wheat advanced breeding lines in paired organic and conventional plant breeding nurseries. They found significant genotype $\times$ farming system interaction at 4 of 5 locations and very low to moderate genetic correlation between organic and conventional systems, leading to the conclusion that indirect selection in conventional systems was less efficient than direct selection in organic systems for identifying the best genotypes for the latter. Important interactions were also found by Legzdina et al. (2007) for yield in barley genotypes grown under organic and conventional conditions. Using the same approach in winter wheat, Brancourt-Hulmel et al. (2005) as well as Sinebo et al. (2002), found that the relative efficiency of indirect selection in conventional highinput conditions over the efficiency of direct selection in different low-input environments ranged from 0.35 to 0.99 in barley. It is also possible to make an a posteriori assessment of indirect versus direct selection: Ceccarelli and Grando (1991) evaluated more than 800 barley breeding lines in 8-10 environments classified as low yielding (LY) or high yielding (HY). The best lines selected in LY always outperformed the best lines selected in HY when evaluated in LY.

Contrary to what is usually acknowledged, all these studies, as well as Ceccarelli (1989) in a review, pointed out that genetic variances or heritabilities were not always lower in stressed environments. This together with the frequent low genetic correlation between a given trait assessed in a stress/low-input/ organic environment and the same trait in conventional/high-input environment provide a possible explanation for the poor efficiency of the indirect selection experiments reviewed here.

The question of the importance of genotype by farming system interaction and of the correlation between genotype performance in OA and CA have also been studied using variety testing trials that have recently become available in several European countries. Research projects have been started to gain more insight into this question and results have been analysed by Przystalski et al. (2008). Genetic correlations between the two systems were described for a range of traits observed in variety trials in conventional and organic growing systems that had values in the range $0.8-1.0$. However, this does not imply that the top ten varieties would be the same for both systems. They concluded, therefore, that combining information from conventional and organic trials would be the optimal approach for selecting varieties for OA. Additional trials have been reported elsewhere; Schwaerzel et al. (2006) concluded for Swiss VCU tests that winter wheat varieties behaved in a similar way in organic farming and extensive conditions. On the contrary, Baresel and Reents (2006) in a study of a large number of German variety trials under high-input, low-input and organic growing conditions, found substantial differences in ranking of the varieties.

In a Danish study of genotype-environment interactions for grain yield involving conventional and organic farming systems including 72 spring barley varieties and 17 combinations of location, growing system and year, choice of variety was found to be as important a factor for grain yield as other factors in the management (Østergård et al. 2006). Specifically, the genotype $\times$ environment interaction contributed about $35 \%$ of the total variation among varieties in conventional or well fertilised organic environments but as much as $80 \%$ for those growing in the extreme organic environments without application of manure. This supports the idea that genotype-environment interactions are most important in extreme environments.

Thus the likelihood of obtaining significant correlations of variety performance under organic and conventional conditions will depend, partly, on the nature of the systems under consideration, and partly, on the interactions of those systems with the environmental conditions during the period of observation. A compromise would be to include selection under organic conditions in a later stage of the breeding process, e.g. F6, after selecting first under 'regular' conventional conditions (Löschenberger et al. 2008, this issue).

Centralised versus decentralised breeding

The term "decentralised" is synonymous with "in situ" or "on farm" and refers to direct selection within the target environment (see below). Decentralised breeding allows a better fit to the target 
environment than breeding only under organic conditions in "centralised" or "ex-situ" experiments at a research station. Decentralised selection is a powerful methodology to fit crops to the physical target environment and to the cropping system. However, crop breeding based on decentralised selection can miss its objectives if it does not utilize farmers' knowledge of the crop and the environment, because it may then fail to fit crops to the specific needs and uses of farmer's communities. As a consequence, decentralised selection is often associated with participatory selection. These approaches are more appropriate to the specific needs of Regional market farming or Local market farming as defined earlier.

\section{Participatory approaches}

Participatory plant breeding (PPB) can be defined as the involvement of several partners (e.g. farmers, traders, consumers, breeders, researchers) in the selection process and is based on the complementarity of skills and knowledge of each partner.

As organic systems are characterized by a wide range of environments and management systems and by a diversity of potential markets (see Table 1), a more direct involvement of larger numbers of actors can raise more issues for crop characterisation than may be considered in conventional breeding (Desclaux et al. 2008). Such issues may include ease of harvest and storage, taste, cooking and nutritional qualities, rate of crop maturity, weed competitiveness, suitability of crop residues as livestock feed and harmony in the plant growing process (Morris and Bellon 2004).

In practice, three kinds of participation are usually distinguished: consultative (information sharing), collaborative (task sharing), and collegial (sharing responsibility, decision making, and accountability) (Sperling et al. 2001; Desclaux and Hedont 2006). The type of participation may determine whether the breeding activity is centralised or decentralised. Although PPB is usually decentralised, it can also be carried out in centralised research stations where farmers are invited to visit, give their opinions and practice selection among plants being grown at the station.

Despite the great diversity of PPB approaches, and of their objectives (improving adaptation, promoting genetic diversity, empowering farmers and rural communities), all have in common the aim of shifting the focus of plant genetic improvement research towards the local level by directly involving the enduser in the breeding process (Morris and Bellon 2004). This interactive approach to breeding may provide the intensity of collaboration which is so crucial to organic agriculture (Lammerts van Bueren et al. 2003). Not only for practical but also for ethical reasons, organic breeding justifies the involvement of farmers and endusers in a PPB programme (Desclaux 2005). Indeed, PPB can provide a relevant fit to the principal aims of organic agriculture for production and processing as prescribed by International Federation of Organic Agriculture Movements (IFOAM 2005b), and especially: "(i) to maintain and conserve genetic diversity through attention to on-farm management of genetic resources, (ii) to recognise the importance of, and protect and learn from, indigenous knowledge and traditional farming systems".

Though more appropriate, or even essential, in the developing world, there is an increasing number of PPB projects in Europe, especially under organic conditions and they can play a key role in evaluating diversity at different scales (e.g. field, farms, village, production basin) using mixtures, populations or inter-cropping (Desclaux and Hedont 2006). Based on studies conducted in several developing countries (e.g. Almekinders and Hardon 2006), the use of many different genotypes within an area can generate genetic mosaics that may be helpful in delaying the development of epidemics and plagues.

\section{Crop structure}

The most common genetic structure of varieties bred in self-pollinating cereals is the pedigree pure line, which means that environmental buffering is dependent on intra-genotypic compensation ability and flexibility, promoted by the allohexaploid genome structure of wheat. It is therefore of interest to consider genetically more diverse structures such as mixtures or populations which allow for complementation and compensation among different plant neighbours. This is particularly important for the more variable environments encountered in OA. Maintaining genetic diversity within a "variety" might allow for more buffering capacity at both the spatial and the temporal levels. For example, variety mixtures can provide functional diversity that limits pathogen and pest 
expansion thus stabilizing yields under disease pressures (Wolfe 1985; Finckh et al. 2000).

Simple mixtures can be advantageous in OA (Østergård et al. 2005), but they may also be less consistent in OA and low-input systems relative to $\mathrm{CA}$, probably because of the limited genetic variation, but also the need to ensure that component varieties 'nick' together (Phillips et al. 2005). The optimal use of genetic diversity can be obtained by breeding populations derived from composite or more simple crosses or possibly from the consecutive harvest and re-sowing of mixtures of genotypes, because the "variety" in this case may adapt specifically to the local conditions and, if managed appropriately, may also respond continuously to environmental changes over time. Such approaches are based on the founding work that Harlan and Martini (1929), Suneson (1960) and Allard (1988, 1990) developed on barley composite cross populations in California from 1928. The authors showed in particular that the average yield of the different populations increased over time as a result of natural selection and competition among plants. In another long-term experiment, Goldringer et al. (2006) and Paillard et al. (2000a, b) showed that wheat composite cross populations grown for 10 generations in different environments were significantly differentiated for adaptive traits such as earliness components and powdery mildew resistance. Such evolutionarybreeding methods are now being developed in OA associated with participatory approaches allowing, simultaneously, for direct selection in a specific targeted environment, for beneficial farmer involvement and for further adaptation to environmental changes (Murphy et al. 2005; see also Phillips and Wolfe 2005, for a review). Well-designed composite crosses also underpin the concept of "modern landraces", based on the founder effect, which can provide rapid adaptation to local, specialised conditions. At a higher level of diversity, i.e. intercropping, which introduces an even wider range of environmental variables, populations offer the potential for rapid adaptation of the crop to a range of different systems with different crop components.

The logic in favour of the development and use of mixtures and populations is increasing rapidly in a changing world. But there are many questions, such as how many, and which, parents to use (see Witcombe and Virck 2001). However, unlike mixtures, populations with the same numbers of 'parents', provide the potential for more stable performance across variable environments because of their greater genetic variation, plant-to-plant interaction and ability to respond to different environments. The latter will be of high importance given the problems of global climate change. Another question with populations is to determine the spatial and temporal levels at which there may be useful adaptation. There is also a need for more information about the usefulness of the grain from such heterogeneous crops for milling, baking and other processing. It is likely that the uptake of such approaches will be more acceptable and rapid in the local marketing sector followed by the regional and then the global (Table 1).

\section{Required characteristics in breeding for organic agriculture}

Physiological and agronomic research, together with field experience, provide insights into the range of characters needed for OA. These include efficient use of a wide range of nutrients and water, weed competition, disease and pest resistance, quality for end use as well as yield and yield stability. The list of potentially important characteristics is enormous and impracticable to consider one by one. As pointed out above, new methods can help in combining traits and their interaction with the environment, but a further four considerations may also be valuable:

(1) to try to identify pleiotropic characters that may have a positive value for a wide range of physiological needs. This could include, for example, vigorous early growth which is valuable in terms of weed competition, uptake of nutrients when they are available and competition particularly against soil-borne disease and pests.

(2) initially at least, to concentrate on major characters that integrate many minor and variable characters, such as yield of grain, yield of protein and yield of straw, or their equivalents in other crops.

(3) to identify characters that can contribute to the crop rotation as a whole rather than only to the cereal crop, for example, root systems that are 
adapted to AM (arbuscular mycorrhizas) colonisation, which can help soil structure and nutrition for subsequent crops as well as for the cereal itself.

(4) because the many characteristics needed will be required to be effective under a wide and rapidly changing range of environmental conditions, the question arises whether it would be more valuable to consider heterogeneous crops (mixtures or populations) which can incorporate many more of the required characters and could allow complementation and compensation among the different genotypes

\section{Factors determining nutrient efficiency}

Mineralization of organic fertilisers depends on soil life activity which in turn depends on soil temperature and conditions. Thus, climatic or soil characteristics often result in secondary nutritive or biotic stresses, which may become limiting factors for yield and quality. Consequently, nutrient use and uptake efficiency (NUUE) is of particular importance in breeding for OA. We limit our considerations here to nitrogen, the most important single determinant for yield and quality, and phosphorus, which is likely to become more important since there is little or no application currently in OA.

Nitrogen Nitrogen supply in OA depends mainly on symbiotic $\mathrm{N}$-fixation supplemented by organic fertiliser. Particularly towards northern Europe, most $\mathrm{N}$ is fixed by fodder legumes in grass-clover mixtures which makes the amount of $\mathrm{N}$ introduced into the system often suboptimal, varying greatly in amount between relatively intensified OA systems and more extensive approaches. Its availability is not easily controllable (Mäder et al.2002) and dependent on the mineralization of crop residues and green or farmyard manure, and possible application times are limited. The results are high mineral $\mathrm{N}$ content in the soil immediately after ploughing, when the uptake ability of winter cereals is low, and N-losses during the winter. In the later growth stages of cereals, the demand from the plants is often much greater than the supply from mineralization: matching $\mathrm{N}$ need and mineralization is, indeed, one of the major problems in OA (Panga and Leteya 2000).

To compensate for the relatively low $\mathrm{N}$ availability in OA systems, the potential for grain protein production has to be higher than in conventional agriculture. This means that total $\mathrm{N}$ uptake into the grain has to be improved in order to maintain yield levels, which depends on (1) total uptake from the soil, (2) translocation from the vegetative tissues to the developing grain, (3) direct transfer from the soil to the grain after anthesis, and (4) losses of nitrogen already absorbed (Barbottin et al. 2005; Bertholdsson and Stoy 1995; Pommer 1990; Papakosta 1994). Genetic differences concerning these characteristics have been shown and may be used to improve adaptation to special environmental conditions (Przulj and Momcilovich 2001a, b; Baresel 2008; Kichey et al. 2007). How new varieties are selected will depend on the time course of $\mathrm{N}$-mineralization. If $\mathrm{N}$-mineralization after anthesis is limiting, pre-anthesis uptake and translocation become more important resulting in varieties with more vegetative tissues, lower harvest indexes and higher biomass. More "conventional" types would be better adapted to environments where considerable amounts of $\mathrm{N}$ are still available after anthesis (Baresel 2006).

Although nitrogen (as nitrate) is mobile in the soil, an extended root system may enhance nitrate uptake in N-limited conditions (Cox et al. 1985; Laperche et al. 2006), and differences in extension of the root system may explain part of the differences in NUUE as shown from studies in maize (Feil et al. 1990; Wiesler and Horst 1994; Laperche et al. 2006). Root symbiosis and interactions with the soil micro flora may also be of importance for N-uptake. Associations with $\mathrm{N}$-fixing bacteria such as Azospirillum are of limited importance for nitrogen assimilation, but positive effects on root development and thus water uptake have been shown (Kapulnik et al. 1987). A priming effect on soil bacteria of the rhizosphere via exudates, stimulating $\mathrm{N}$ mineralization, is likely (Kuzyakov 2002), but its relevance for plant growth is unknown. There is evidence that associations with bacteria in the rhizosphere are dependent on genotype in wheat (Kapulnik et al. 1987), but direct selection for this trait would be difficult and its effect on NUUE and yield is uncertain.

\section{Phosphorus}

At present, $P$ availability is rarely an issue because immediately after conversion from conventional to organic agriculture, the content of available $P$ in the 
soil is often high and decreases only slowly over many years (Oehl et al. 2002; Gosling and Shepherd 2005). Nevertheless, $P$ recycling and/or better exploitation of the (large) immobile fraction have to be improved in the long-term, so development of more $P$-efficient varieties will become more important. Phosphorus has low mobility in the soil and its uptake efficiency is dependent on soil exploration by roots, root hairs (possible for indirect selection: Gahoonia and Nielsen 2004a, b) and especially arbuscular mycorrhizas (AM), whose absorbing surface is much larger and of low cost to the plant relative to roots and root hairs (Bolan 1991). Numerous studies have shown that AM colonisation and the plant benefit from the symbiosis are dependent on the genotype (Baon et al. 1993; Hetrick et al. 1993; Manske et al. 1995). Breeding for this character could be successful as a long-term objective.

It can be concluded that there is a considerable potential in breeding for improved nutrient efficiency by selecting under conditions which correspond to the target environments. This is particularly important in conditions of low availability of nitrogen or phosphorus.

\section{Competitive ability against weeds in OA}

Weed management is essential for successful organic crop production with the aim to suppress undesirable weeds such as aggressive grasses, creeping thistle (Cirsium arvense), broad-leaved dock (Rumex obtusifolius) and crop volunteers, whilst finding a balance between the plants of crops and other more desirable wild plants. Plant traits that confer a high degree of crop competitive ability, especially against aggressive weeds, are highly beneficial in organic farming (Mason and Spaner 2006). Both plant (e.g. height) and crop characteristics (e.g. ground cover) are important as selection criteria. However, competitive traits are unlikely to have received sufficient attention, or high priority, in conventional plant breeding, except indirectly, for example, through early vigour. This is largely because selection for competitiveness could be at the expense of other important criteria (Brennan et al. 2001) and large genotype $\times$ environment $\times$ management interactions can mean difficulty in phenotypic selection for competitiveness (Coleman et al. 2001).
Nevertheless, there appears to be sufficient genetic variation in crop competitive ability (Acciaresi et al. 2001; Coleman et al. 2001; Hoad et al. 2006) for such selection to be introduced into breeding programmes (Hoad et al. 2008). Older genotypes are often more competitive than recent introductions (Lemerle et al. 2001a; Bertholdsson 2005). Competitive ability is usually not attributed to a single characteristic, either within or between varieties (Pester et al. 1999; Lemerle et al. 2001b), but the interaction among a series of desirable characteristics is important (Eisele and Köpke 1997; Mason and Spaner 2006).

Early crop vigour is associated with increased competitive ability (Rebetzke and Richards 1999; Pester et al. 1999; Lemerle et al. 2001a, b; Acciaresi et al. 2001; Bertholdsson 2005). Early season crop ground cover confers later competitiveness against weeds (Cousens and Mokhtari 1998; Lemerle et al. 1996; Huel and Hucl 1996). Traits associated with high ground cover include rapid early growth rate (Froud-Williams 1997), high tillering ability (Lemerle et al. 2001a) and planophile leaf habit with high leaf area index (Huel and Hucl 1996; Lemerle et al. 1996). Ground cover is also influenced by agronomic factors such as drilling row width and seed rate (Lemerle et al. 2004).

Plant height is widely reported as an important trait for increasing crop competitiveness (Gooding et al. 1993). Taller varieties are likely to be more competitive than shorter ones as competition for light increases (Cudney et al. 1991). The relative importance of plant height decreases if compensated for by other traits. For example, a short planophile genotype with rapid leaf canopy development and high leaf area index may have higher weed suppression than a tall genotype without these other traits.

Shading ability is a good measure of overall competitive ability of a genotype (Eisele and Köpke 1997). Even small differences in shading ability or the percentage of light intercepted can have a significant affect on weed growth. It would be advantageous if selection for above-ground competitiveness was integrated with improvements in nitrogen use efficiency, root competition and allelopathy (Bertholdsson 2004, 2005). One objective might be to establish if genotypes with enhanced early nitrogen uptake efficiency resulted in further improvements in weed suppression. However, many 
of the physiological traits for desirable below-ground criteria are less well understood, or less practical for use by plant breeders in their selections. Variation in allelopathic effects on weeds has been identified from in-vitro testing (Wu et al. 2000; Bertholdsson 2004), but little is known about in-vivo behaviour. It is difficult to separate allelopathy from other characteristics of crop competitive ability (Bertholdsson 2005). Consequently there may be as yet unexplored potential for the selection of varieties showing a high allelopathic activity against weeds (Olofsdotter et al. 2002). More promising might be the selection for genotypes with high early nitrogen uptake efficiency amongst those already recognised as having good ground coverage and shading ability.

\section{Breeding for disease resistance}

Disease resistance is a major issue in cereal breeding for both conventional and OA. However, plant health in $\mathrm{OA}$ is a broader concept involving not only the use of resistant varieties with different morphological traits, but also of agronomic measures that reduce the risk of high disease levels (e.g. tillage, rotation), as well as other features of OA such as lower plant population densities and lower nitrogen levels that may reduce infection and spread of disease.

The most recognized diseases in OA are the bunts and smuts in wheat, barley, and oats, Septoria diseases in wheat, leaf stripe disease (Drechslera graminea) in barley, Fusarium head blight (FHB) in wheat, triticale, and rye (Wilbois et al. 2005) and ergot in rye. If deployment of regional cultivars is increased, the number and relevance of critical diseases can be reduced. In dry regions, for example, the bunts and smuts might be the only diseases important for OA.

Generally, diseases that are strongly influenced by sowing time, plant population density and nitrogen nutrition such as powdery mildew, rusts and foot rot are less important in OA. They occur later and with lower incidence, thus producing less damage (Letourneau and Van Bruggen 2006). However, soilborne diseases, such as $S$. tritici blotch and Drechslera tritici-repentis in wheat, FHB in all cereals, and ergot (Claviceps purpurea) are of significant economic importance. If control by cultural measures is possible, their damage might be considerably less in OA. A third group of mainly seed-borne diseases, the bunts and smuts, is among the most important because there are hardly any practical and effective seed dressings in OA.

In wheat, most commercial European varieties are highly susceptible to common bunt (Tilletia tritici and Tilletia laevis) and dwarf bunt (Tilletia controversa), because conventional breeders have no interest in breeding for resistance to these diseases. A few fairly resistant varieties have been described (Fischer et al. 2002; Dumalasová and Bartoš 2006; Wächter et al. 2007), but resistance tests are reliable only when several locations and years and a defined bunt inoculum are used. All resistance deployment strategies are possible, but it is not clear which races are prevalent in Europe. In a first attempt to improve bunt resistance, variety tests should be organised at several locations and the bunt races occurring in different regions need to be monitored.

Fusarium head blight (FHB), caused by Fusarium graminearum, Fusarium culmorum and other Fusarium species has gained increasing attention in the temperate wheat producing areas because of yield losses and mycotoxin contamination of grain, especially by deoxynivalenol (DON). As long as maize as a pre-crop and reduced/no tillage is not an option in $\mathrm{OA}$, the disease incidence should be lower than in conventional farming. But in Central Europe, FHB remains problematic in years with frequent rainfall during flowering. FHB resistance is quantitatively inherited; no source with complete resistance is yet known. FHB resistance in wheat can be supported by morphological characters that are, however, mostly unwanted in intensive agricultural systems: tallness, especially through absence of the height-reducing $R h t$ genes, large distance between canopy and head, and less dense heads (Mesterhazy 1995; Hilton et al. 1999). Given the high reputation of OA for quality of food and feed, FHB resistance should have a high priority in the choice of varieties.

In conclusion, OA needs resistance breeding, but the overall approach, together with the pattern of diseases and their significance, is somewhat different from conventional farming. OA in general aims at a broader approach to disease resistance combining morphological and physiological traits to ensure overall plant health instead of absolute, specific resistance. More specifically, concerning FHB and Septoria diseases, OA can benefit from the work of conventional breeders in terms of resistance sources 
for crossing purposes or by growing conventionally bred varieties. For the bunts and smuts, new resistance breeding programmes should be built up to guarantee secure organic seed production through all generations of multiplication from breeding to certified seed. Whether variety mixtures can control bunts and smuts more durably through the deployment of several race-specific resistance genes has yet to be investigated. Additional traits for $\mathrm{OA}$ are resistance to other seed-borne diseases (Wilbois et al. 2005).

\section{Quality}

\section{Baking quality}

Next to yield, the most important basic breeding aim for wheat is quality for milling and baking. The precise needs vary, however, depending on the market use. For the global model, supermarkets usually depend on industrialised milling and baking, using cereals with a constant and high protein content, with relatively hard gluten. Cereals for regional and local markets are often produced for artisanal milling and baking, in which there is more flexibility, for example, to adjust the baking process to the quantity and quality of the proteins, or to mixtures of different types of flour. However, for wholemeal bread products, the process can be complicated because the high fibre content itself can modify the behaviour of the gluten (Rakszegi et al. 2006).

Breeding for baking quality in wheat is determined largely by the common negative correlation between yield and grain protein. Over recent decades, wheat breeding for CA has concentrated on yield, so that newer varieties, generally, have higher yields and lower grain protein. To compensate for this, there has been selection for higher gluten quality, together with improved fertiliser distribution over the season (Canevara et al. 1994; Baresel 2006). This means that in OA, with limited opportunities for improved fertiliser distribution, the same modern varieties have lower yields together with levels of protein that often do not fulfil the requirements of the baking industry. The effect of reduced $\mathrm{N}$ input may vary however with the climatic conditions: in continental or Mediterranean climates, where drought occurs often during grain filling, protein contents and consequently baking quality, may be considerably higher than in temperate climates.

The main aim for breeding for OA must therefore be to dissociate yield from grain protein, so that, even at relatively low yield levels, the grain produced can have acceptable baking quality. This goal is being sought currently by OPB breeders in Switzerland and Germany (personal communications). Since there is little GEI for grain protein content and gluten quality, specific selection for the latter for OA (Kempf 2002), may prove difficult.

However, the lack of GEI also means that selection for quality traits can be indirect (Kleijer and Schwaerzel 2006; Baresel 2006), for example, under CA conditions, including also the use of HMWGS (High Molecular Weight Glutenin Subunits) markers. A problem might be that most varieties with high protein content often have softer gluten, which reduces baking quality. A future challenge in breeding for organic farming (or other systems with low nitrogen input) will be, therefore, to develop good lines combining high protein content with high gluten quality.

\section{Malting quality}

Organic barley for malting is based predominantly on local supply and use to small, but growing, niche markets, for example micro-breweries. Nevertheless, barley grown for organic malt production should be required to meet the same quality criteria as barley used in conventional malting for brewing, distilling or other food uses. Selection for high malting quality in OA should benefit from advances in breeding for generic (or most essential) malting characteristics. Work by Ogushi et al. (2002) also indicated that selection of high quality malting genotypes could be based on their malting data when grown in another, contrasting, environment. These, and similar, findings suggest a high degree of predictability of malting performance across contrasting environments ( $\mathrm{Lu}$ et al. 1999; Molina Cano et al. 1997) which is encouraging for $\mathrm{OA}$ if improvements in malting quality are based largely within conventional breeding. Specific requirements for OA would need to be introduced later into the selection process. These requirements could include agronomic traits such as disease resistance to reduce contamination of the ears and weed competitiveness to reduce admixture in the bulked grain. 


\section{Nutritional quality}

Nutritional quality is one of the critical questions in marketing organic food. Although it is hard to find definitive data in the literature, the available information suggests that organically produced, cerealbased foodstuffs can have several advantages. First, they are usually free from pesticides and pesticide residues, resulting in a decrease in allergenic reactions. At the same time, they contain significantly more antioxidants (especially fat soluble antioxidants), probably because of more severe abiotic stress during cultivation (Grinder-Pedersen et al. 2003). Indeed, in organic produce, increased antioxidants and bioactive compounds important in plant defence systems seem to be a general feature (Mitchell and Chassy 2004), making them an excellent source of functional and dietary food (Kovács 2006). Concerning mineral nutrients, Murphy et al. (2008) argue that, from their experience, breeders should be able to increase mineral concentration in modern cultivars without negatively affecting yield.

For the under-utilised hulled wheat species, such as einkorn and emmer, the situation is even more promising, since they contain significantly larger amounts of essential microelements $(\mathrm{Cu}, \mathrm{Zn}, \mathrm{Fe}, \mathrm{Ca}$, $\mathrm{Mg}$ ) (Bálint et al. 2001), different amino acid profiles, and relatively high amounts of essential fatty acids (Kovács and Szabó 2006). Moreover, there is considerable variation in gluten content relative to modern wheat, especially in einkorn, where extremely high gluten content (over $45 \%$ wet gluten) and gluten free genotypes (important for coeliac diseases) sometimes occur together in the same population (Kovács and Szabó 2006). Such species are difficult to grow in CA, because they are often highly sensitive to herbicides, and unproductive at high $\mathrm{N}$ levels (Bedő and Kovács 2006).

\section{Breeding techniques}

In vitro techniques

Because organic agriculture is a process rather than a product oriented approach, the development of organic breeding is concerned with the values of 'naturalness' (Lammerts van Bueren et al. 2003, 2007; Lammerts van Bueren and Struik 2004). As a consequence, the draft standards for organic breeding programmes exclude the use of in-vitro techniques (IFOAM 2005a). If IFOAM does decide in future to exclude in-vitro techniques, this would have consequences, for example, in barley and wheat breeding where embryo or microspore culture is used together with colchicine application for doubling haploids. A potential problem regarding the availability of varieties suitable for OA is that it may be difficult or even impossible to find out which varieties have been subject to embryo culture in their origins. Attempts are being made, therefore, in some countries (e.g. Hungary, Switzerland) to design a certification system for specific organic breeding programmes (OPB) in which no in-vitro techniques are applied to distinguish the varieties produced from those developed in other types of breeding programme (e.g. BFCA, BFOA).

\section{Use of molecular markers}

In recent years, the reality of using DNA-based molecular markers in plant breeding has grown rapidly, particularly for maize. Uptake for a cereal such as wheat has been slower because of the relative cost of marker screening against the predicted returns from breeding (Koebner 2004). Further constraints for the organic sector lie in the relatively small size of the market together with possible concerns about some production methods for such markers and their application with respect to the violation of plant integrity (Lammerts van Bueren et al. 2005a).

However, as one early example, Rakszegi at al. (2006) successfully applied the technique to introduce a specific glutenin gene from the old Hungarian variety, Bánkuti 1201, into new lines for organic and conventional production. As screening costs fall, we may expect to see an increasing uptake particularly for rapid introduction of disease resistance genes that are currently unavailable in developed material, for example, resistance to bunt and loose smut (see above). Another example could be in backcross programmes to include certain monogenetic disease resistances from wild relatives so as to avoid undesired linkage drag, as in resistance against the barley mosaic virus complex (Werner et al. 2005).

A further recent application relevant to this review is the use of marker assisted selection (MAS) to help to increase the success rate in selection in 
participatory plant breeding (Steele et al. 2004). This was achieved in India and Nepal, improving the drought resistance of rain-fed rice by incorporating quantitative trait loci (QTL) for root performance into an older popular variety.

Overall, some promising applications for MAS in organic breeding will be to follow QTLs associated with complex characters, for instance, NUUE and weed competition, under different environmental conditions. Fortunately, methods are emerging that can improve the efficiency of selection for complex characters (Podlich et al. 2004) and provide a better understanding of the genetic architecture of such traits as observed across environments by incorporating QTL by Environment interactions (QxE). Statistical approaches analysing QxE have been proposed in the context of QTL detection (Boer et al. 2007) or association studies that are based on complex population structures but provide the advantage of analysing more diverse QTL alleles (Crossa et al. 2007). In the long-term, such complex statistical approaches derived from animal or human genetics will allow analysis of complex population structures such as multiparental populations that have evolved in different environments. Such methods are likely to be of value in improving our understanding of the genetical changes involved in the responses of populations to different forms and levels of selection, which should be helpful in improving the design of mixtures and populations for particular cropping systems. Such advance will be dependent on decreasing costs for the use of multiple marker assessments and development of the appropriate statistical approaches for inbreeding plants (Jannink et al. 2001; Backes and Østegård 2008), together with an increasing interest in research funding for sustainable crop production.

\section{The future development of organic agriculture and plant breeding}

There is no doubt that field trials to compare varietal performance under organic and conventional conditions have provided valuable information, confirming that there can be both differences and similarities, with some varieties showing consistent adaptation to $\mathrm{OA}$ or to CA or to both. However, it is also clear that the kinds of difference and their scale are dependent on many factors, the most important being the exact type of OA or CA system. For this reason, it may be important to resist the temptation to continue with trials comparing variety performance in $\mathrm{OA}$ and $\mathrm{CA}$, unless there is a highly specific objective. Much more important, in our view, is to recognise that within $\mathrm{OA}$ and CA there are different sub-systems, such as those described for OA (Table 1), based on the three marketing levels. Similarly, in CA, there are parallels which involve, for example, significantly different levels of inputs. Overall, for the two kinds of agricultural system, it is more important to recognise the structure of the systems and the impacts of the different inputs that are used or not used. Moreover, it is crucial to recognise how these inputs are changing, or how they will change, as climate and resource availability change.

Concerning OA specifically, it is clear that the application of an ecology-based approach to farming implies a primary concern for the interactions among the selected characters, and among those characters and the whole farming system. Furthermore, the inherently more variable conditions of OA needs particular attention to stability of production, which means that adaptation needs to be applied among many different localities rather than over single, large geographical areas. Such an approach can be achieved only by using a range of different approaches to the breeding process (decentralisation, participation etc.) and to the forms of crop populations that are used (variety mixtures, populations, inter-crops). For all of these approaches, there is a need to ensure that more and novel genetic resources are fed into the start of the breeding processes. In other words, success in any form of local selection is dependent on a broad starting array of genetic resources.

Currently, organic farmers are making use of the most appropriate varieties produced in CA programmes, together with a relatively small amount of material bred specifically for organic systems. This amounts to a somewhat small input. However, important changes appear to be on the way, from three sources. The first relates to developments in the applications of ecology to OA, as indicated above. The second relates to other developments in plant science, particularly through a better understanding of selection for efficient use of resources also as discussed above and, for example, by Geiger et al. 
(2007). The third change lies in the practical observation that varieties bred under organic conditions may be more efficient in resource terms, and higher yielding, when used in CA (Burger et al. 2008).

If these three changes develop further, together with the other methods discussed above, then we should see significant benefits for both OA and CA. For OA specifically, cooperation among all kinds of breeding efforts and testing in a widely distributed trial network on organic farms would enable organic farmers to choose, more rigorously, the varieties best suited to their local conditions. A combination of all of the strategies indicated above would lead to exploitation of the maximum appropriate genetic diversity for organic farming systems. Furthermore, we would also expect to see stimulation of positive interactions among the different breeding strategies being developed.

\section{Some legal concerns}

Legislation for organic varieties varies among European countries. In Austria, Denmark, Germany and Switzerland, for example, VCU tests for organic farming are available and varieties that meet DUS requirements can be evaluated and registered (Donner and Osman 2006). In other European countries such as France and the UK, there is no special VCU testing. Thus, varieties adapted to organic conditions that do not yield sufficiently well under conventional conditions, cannot be registered. And, of course, without registration, the exchange and production of seeds is forbidden. Another current question concerns the potential heterogeneity of, for example, populations, that are not integrated into the legislation. Indeed, varieties that do not comply with DUS cannot be registered. It is urgent that legislation at the European level evolves to take into account the new demands.

In fact, there is no legal problem for marketing seed of variety mixtures as long as all components have passed variety registration and seed certification; indeed, specific mixtures are registered in Denmark. In the case of populations, assuming they prove to be valuable under commercial conditions, the question of IPR/PBR (intellectual property rights/ plant breeders rights) arises: how could they be described and protected? How can quality of populations be assured and misuse prevented? One possibility is the regional/limited use on a small- scale that is perhaps in line with the legislation currently being worked on by the EU. A further possibility under discussion is to abandon the current systems of DUS and VCU which are inappropriate for materials that are under continuous dynamic management. The static variety descriptions would need to be replaced by some form of data-logging of the history of the different populations so that they remain fully traceable wherever and whenever they are used.

\section{Summary conclusions}

Until recently, interest in breeding for OA has been limited to a handful of small-scale breeders. However, rising input prices, the increasing impact of climate change and the need for sustainability are creating a larger opportunity for the specific breeding objectives needed.

The organic sector itself is differentiating roughly into three scales, Global Commodity, Regional and Local Market. Varietal production overall still tends to be a one-way traffic, with varieties bred for CA being screened for use in OA. In particular, the global commodity market is supplied mainly with such varieties. Smaller scale programmes, including breeding directly for $\mathrm{OA}$, tend to be directed towards regional and local markets.

Though many of the characteristics required in new varieties are common to both $\mathrm{CA}$ and $\mathrm{OA}$, there are a number, mostly complex, that have a higher priority in OA. These include characters that are important for the farming system and the crop rotation, for example, weed competition and adaptation to arbuscular mycorrhizas. There is also a need for simultaneous selection of characters such as weed competition, nutrient uptake and disease and pest resistance, which are often helped by positive interactions from early plant vigour.

There is an obvious need for nutrient uptake and use efficiency. For nitrogen, this needs to include improvement of relationships between crop and nitrogen-fixing organisms living either on roots or free-living; a similar conclusion applies to the needs for phosphorus.

Breeding for disease resistance also differs from the CA approach, with the need for plant vigour to encourage general plant health, together with more 
specific approaches for resistance to seed-borne diseases such as bunt and loose smut.

However well these characteristics may be combined, there will always be a need under the conditions of $\mathrm{OA}$ to deal with large genotypeenvironment interactions. For this reason, the potential for decentralised breeding, to select plants in the places that they will be grown, is particularly important for OPB, combined with PPB at different levels from mostly breeder to mostly farmer.

An important tool to help deal with highly variable environments is the use of genetically diverse crops, including inter-cropping, mixtures and populations, which will all play larger roles in OA. Such approaches can also be valuable in helping to restore or increase biodiversity within the crop.

The use of DNA-based molecular markers has so far played only a minor role in breeding for OA. This is likely to change markedly if, on the one hand, there is a further decline in the cost of the technology and, on the other, interest in breeding for OA and the use of within-crop diversity both increase.

Successful application and dissemination of the outcomes from these different approaches to breeding for organic agriculture and the use of diversity will need modifications to be made to the legislative framework for introduction and use of the material in agriculture.

Acknowledgment This work has been carried out within the COST860 SUSVAR Network (http://www.cost860.dk) which is sincerely acknowledged.

Open Access This article is distributed under the terms of the Creative Commons Attribution Noncommercial License which permits any noncommercial use, distribution, and reproduction in any medium, provided the original author(s) and source are credited.

\section{References}

Acciaresi HA, Chidichimo HO, Sarondon SJ (2001) Traits related to competitive ability of wheat (Triticum aestivum) varieties against Italian ryegrass (Lolium multiflorum). Biol Agric Hortic 19:275-286

Allard RW (1988) Genetic changes associated with the evolution of adaptedness in cultivated plants and their wild progenitors. J Hered 79:235-238

Allard RW (1990) The genetics of host-pathogen coevolution. Implication for genetic resources conservation. J Hered $81: 1-6$
Almekinders C, Hardon J (eds) (2006) Bringing farmers back to into breeding, experiences with participatory plant breeding and challenges for institutionalisation. Agromisa special 5. Agromisa, Wageningen

Atlin GN, McRae KB, Lu X (2000a) Genotype $\times$ region interaction for two-row barley in Canada. Crop Sci 40:1-6

Atlin GN, Baker RJ, McRae KB, Lu X (2000b) Selection response in subdivided target regions. Crop Sci 40:7-13

Backes G, Østergård H (2008) Molecular markers to exploit genotype-environment interactions of relevance in organic growing systems. Euphytica. doi:10.1007/s10681-0089729-y

Bálint AF, Kovács G, Erdei L, Sutka J (2001) Comparison of the $\mathrm{Cu}, \mathrm{Zn}, \mathrm{Fe}, \mathrm{Ca}$ and $\mathrm{Mg}$ contents of the grains of wild, ancient and cultivated wheat species. Cereal Res Comm 29:375-382

Baon JB, Smith SE, Alston AM (1993) Mycorrhizal response of barley cultivars differing in $P$ efficiency. Plant Soil 157:97-105

Barbottin A, Lecomte C, Bouchard C, Jeuffroy MH (2005) Nitrogen remobilisation during grain filling in wheat: genotypic and environmental effects. Crop Sci 45:1141-1150

Baresel JP (2006) Weizenzüchtung für den Ökologischen Landbau. Selektionsmöglichkeiten für pflanzenbauliche und Qualitätsmerkmale. Dissertation am Lehrstuhl für Ökologischen Landbau der Technischen Universität München

Baresel JP (2008) Effects of genotype and environment on $\mathrm{N}$ uptake and $\mathrm{N}$ partition in organically grown winter wheat (Triticum aestivum L.) in Germany. Euphytica. doi:10.1007/s10681-008-9718-1

Baresel JP, Reents HJ (2006) Observations on long-term wheat variety trials under organic and conventional conditions in Germany. In: Østergård H, Fontaine L (eds) Proceedings of the COST SUSVAR workshop on cereal crop diversity: implications for production and products. ITAB Press, Paris, France

Bedő Z, Kovács G (2006) Organic breeding and farming of cereals. Agroinform Publishing House, Budapest, Hungarian, p 179

Bertholdsson N-O (2004) Variation in allelopathic activity over 100 years of barley selection and breeding. Weed Res 44:78-86

Bertholdsson NO (2005) Early vigour and allelopathy-two useful traits for enhanced barley and wheat competitiveness against weeds. Weed Res 45:94-102

Bertholdsson NO, Stoy V (1995) Yields of dry matter and nitrogen in highly diverging genotypes of winter wheat in relation to N-uptake and N-utilisation. J Agron Crop Sci 175:285-195

Boer MP, Wright D, Feng LZ et al (2007) A mixed-model quantitative trait loci (QTL) analysis for multiple-environment trial data using environmental covariables for QTL-by-environment interactions, with an example in maize. Genetics 177:1801-1813

Bolan NS (1991) A critical review on the role of mycorrhizal fungi in the uptake of phosphorus by plants. Plant Soil 134:2

Brancourt-Hulmel M, Heumez E, Pluchard P, Beghin D, Depatureaux C, Giraud A, Le Gouis J (2005) Indirect versus direct selection of winter wheat for low-input or high-input levels. Crop Sci 45:1427-1431 
Brennan JP, Lemerle D, Martin P (2001) Economics of increasing wheat competitiveness as a weed control weapon. Contributed paper presented to the 45th Annual Conference of the Australian Agricultural and Resource Economics Society.

Bundesamt für Ernährungssicherheit (2007) Österreichische Beschreibende Sortenliste 2007. Getreide im biologischen Landbau. Bundesamt für Ernährungssicherheit. Schriftenreihe $21 / 2007$

Bundessortenamt (2007) Beschreibende Sortenliste 2007. Deutscher Landwirtschaftsverlag Hannover

Burger H, Schloen M, Schmidt W, Geiger HH (2008) Quantitative genetic studies on breeding maize for adaptation to organic farming. Euphytica. doi:10.1007/s10681-0089723-4

Canevara MG, Romani M, Corbellini M, Perenzin M, Borghi B (1994) Evolutionary trends in morphological, physiological, agronomical and qualitative traits of Triticum aestivum L. cultivars bred in Italy since 1900. European J Agron 3:175-185

Carr PM, Carr HJ, Kandel PM, Porter RD, Horsley RD, Zwinger SF (2006) Wheat cultivar performance on certified organic fields in Minnesota and North Dakota. Crop Sci 46:1963-1971

Ceccarelli S (1989) Wide adaptation: how wide? Euphytica 40:197-205

Ceccarelli S, Grando S (1991) Environment of selection and type of germplasm in barley breeding for low-yielding conditions. Euphytica 57:207-219

Coleman RD, Gill GS, Rebetzke GJ (2001) Identification of quantitative trait loci for traits conferring weed competitiveness in wheat (Triticum aestivum). Aust J Agric Res 52:1235-1246

Comstock RE, Moll RH (1963) Genotype-environment interaction. In: Hanson WD, Robinson RF (eds) Statistical genetics and plant breeding. Publ. 982. National Academy of Science-National Research Council, Washington, DC, pp 194-196

Council Regulation (EC) (2007) No 834/2007: http://eurlex.europa.eu/LexUriServ/site/en/oj/2007/1_189/ 1_18920070720en00010023.pdf cited 10 December 2007

Cousens RD, Mokhtari S (1998) Seasonal and site variability in the tolerance of wheat cultivars to interference from $\mathrm{Lo}$ lium rigidum. Weed Res 38:301-307

Cox MC, Qualset CO, Rains DW (1985) Genetic variation for nitrogen assimilation and translocation in wheat. II. Nitrogen assimilation in relation to grain yield and protein. Crop Sci 25:435-439

Crossa J, Burgueno J, Dreisigacker S et al (2007) Association analysis of historical bread wheat ger mplasm using additive genetic covariance of relatives and population structure. Genetics 177:1889-1913

Cudney DW, Jordan LS, Hall AE (1991) Effect of wild oat (Avena fatua) infestations on light interception and growth rate of wheat (Triticum aestivum). Weed Sci 39:175-179

de la Vega AJ, Chapman SC (2006) Defining sunflower selection strategies for a highly heterogeneous target population of environments. Crop Sci 46:136-144

de la Vega AJ, Chapman SC, Hall AJ (2001) Genotype by environment interaction and indirect selection for yield in sunflower. I. Two-mode pattern analysis of oil and biomass yield across environments in Argentina. Field Crops Res 72:17-38

Desclaux D (2005) Participatory plant breeding methods for organic cereals: review and perspectives. In: Lammerts van Bueren ET, Goldringer I, Østergård H (eds) Proceedings of the COST SUSVAR/ECO-PB workshop on organic plant breeding strategies and the use of molecular markers, 17-19 January 2005, Driebergen, The Netherlands. Louis Bolk Institute, Driebergen, The Netherlands

Desclaux D, Hedont M (2006) Proceedings of ECO-PB workshop participatory plant breeding: relevance for organic agriculture? 11-13 June 2006, La Besse, France. ITAB, Paris, France

Desclaux D, Nolot JM, Chiffoleau Y, Gozé E, Leclerc C (2008) Changes in the concept of genotype $\times$ environment interactions to fit agriculture diversification and decentralized participatory plant breeding - pluridisclipinary points of view. Euphytica. doi:10.1007/s10681-0089717-2

Donner D, Osman A (eds) (2006) Handbook Cereal variety testing for organic and low-input. Available through COST SUSVAR http://www.cost860.dk/publications/ handbook cited 10 December 2007

Dumalasová V, Bartoš B (2006) Resistance of winter wheat cultivars to common bunt, Tilletia tritici (Bjerk.) Wiint. aind T. leavis Kühn. J P1 Dis Prot 113:159-163

Eisele JA, Köpke U (1997) Choice of variety in organic farming: new criteria for winter wheat ideotypes 1: light conditions in stands of winter wheat affected by morphological features of different varieties. Pflanzenbauwissenschaften 1:19-24

Faberova I, Le Blanc A (1996) Status of wheat genetic resources in Europe. In: Gass T et al (eds) Report of a workshop on wheat genetic resources. IPGRI, Rome

Falconer DS (1952) The problem of environment and selection. Am Nat 86:293-298

Falconer DS, Mackay TFC (1996) Introduction to quantitative genetic. Longman, Harlow

Feil B, Thiraporn R, Geisler G, Stamp P (1990) Root traits of maize seedlings- indicators of nitrogen efficiency? Plant Soil 123:155-159

Finckh MR, Wolfe MS (2006) Diversification strategies. In: Cooke BM, Jones DG, Kaye B (eds) The epidemiology of plant diseases. Springer Verlag, New York

Finckh MR, Gacek ES, Goyeau H, Lannou C, Merz U, Mundt CC, Munk L, Nadziak J, Newton AC, de VallavieillePope C, Wolfe MS (2000) Cereal variety and species mixtures in practice, with emphasis on disease resistance. Agronomie 20:813-837

Fischer K, Schön CC, Miedaner T (2002) Chancen der Resistenzzüchtung gegen Brandpilze bei Weizen für den Ökologischen Pflanzenbau. University of Hohenheim, Stuttgart, Germany

Froud-Williams RJ (1997) Varietal selection for weed suppression. Asp Appl Biol 50:355

Gahoonia TS, Nielsen NE (2004a) Barley genotypes with long root hairs sustain high grain yields in low- $P$ field. Plant Soil 262:55-62

Gahoonia TS, Nielsen NE (2004b) Root traits as tools for creating phosphorus efficient crop varieties. Plant Soil 260:47-57 
Geiger HH, Schmidt W, Burger H (2007) Quantitative-genetic basis of breeding maize for adaptation to organic and lowinput farming. In: Lammerts van Bueren ET, Goldringer I, Scholten $\mathrm{O}, \varnothing$ stergård $\mathrm{H}$ (eds) Plant breeding for organic and sustainable, low-input agriculture: dealing with genotype $\times$ environment interactions. Book of abstracts of the Eucarpia symposium of working group organic plant breeding 7-9 November 2007, Wageningen, The Netherlands

Goldringer I, Prouin C, Rousset M, Galic N, Bonnin I (2006) Rapid differentiation of experimental populations of wheat for heading-time in response to local climatic conditions. Ann Bot Lond 98:805-817

Gooding MJ, Thompson AJ, Davies WP (1993) Interception of photosynthetically active radiation, competitive ability and yield of organically grown wheat varieties. Asp App Biol 34:355-362

Gosling P, Shepherd M (2005) Long-term changes in soil fertility in organic arable farming systems in England, with particular reference to phosphorus and potassium. Agric Ecosyst Environ 105:425-432

Grausgruber H, Arndorfer M (2002) Current situation of einkorn (Triticum monococcum subsp. monococcum) and emmer (Triticum turgidum subsp. dicoccum) cultivation in Austria. In: Marè C, Faccioli P, Stanca AM (eds) From biodiversity to genomics: breeding strategies for small grain cereals in the third millennium. Experimental Institute for Cereal Research, Fiorenzuola d'Arda, Italy

Grinder-Pedersen L, Rasmussen SE, Bügel S, Jørgensen LV, Dragsted LO, Gundersen V, Sandström B (2003) Effect of diets based on foods from conventional versus organic production on intake and excretion of flavonoids and markers of antioxidative defense in humans. J Agric Food Chem 51:5671-5676

Hammer K, Gladis Th (2001) Nutzung genetischer Ressourcen-ökologischer Wert der Biodiversität Schriften Genetik Resourcen, vol 16. Zadi, Bonn

Hänsel H, Fleck A (1990) Reaktion verschiedener Winterweizen bezüglich Kornertrag, Proteingehalt und Proteinertrag auf das Produktivitätsniveau in Versuchen ohne Fungizid- und CCC-Behandlung im Trockengebiet (Ein Beitrag zur Low-Input-Diskussion). Bericht über die Arbeitstagung 1990 der Arbeitsgemeinschaft der Saatzuchtleiter, 20-22 November 1990 in Gumpenstein. Verlag und Druck der Bundesanstalt für alpenländische Landwirtschaft Gumpenstein

Harlan HV, Martini ML (1929) A composite hybrid mixture. J Am Soc Agron 21:487-490

Hetrick BAD, Wilson GWT, Cox TS (1993) Mycorrhizal dependence of modern wheat cultivars and ancestors-a synthesis. Can J Bot 71:512-518

Heyden B (2004) Erfolgreiche Weizenzüchtung im biologischdynamischen Landbau, Ein Vergleich der aktuellen Zuchtstämme und -sorten an sechs Standorten. Lebendige Erde 4:44-47

Hill J, Becker HC, Tigerstedt PMA (1998) Quantitative and ecological aspects of plant breeding. Chapman \& Hall, London, UK

Hilton AJ, Jenkinson P, Hollins TW, Parry DW (1999) Relationship between cultivar height and severity of Fusarium ear blight in wheat. Plant Pathol 48:202-208
Hoad SP, Davies DHK, Topp CFE (2006) Designing crops for low-input and organic systems: enhancing wheat competitive ability against weeds. Proceedings crop protection in northern Britain

Hoad SP, Topp CFE, Davies DHK (2008) Selection of cereals for weed suppression in organic agriculture: a method based on cultivar sensitivity to weed growth. Euphytica. doi:10.1007/s10681-008-9710-9

Hoisington DM, Khairallah M, Reeves T, Ribaut JM, Skovmand B, Taba S, Warburton M (1999) Plant genetic resources: what can they contribute toward increased crop productivity? Proc Natl Acad Sci USA 96: 5937-5943

Huel DG, Hucl P (1996) Genotype variation for competitive ability in spring wheat. Plant Breed 1996:325-329

IFOAM (2005a) The IFOAM norms for organic production and processing, version 2005. IFOAM, Bonn, Germany

IFOAM (2005b) Principles of organic agriculture-preamble. Available via http://www.ifoam.org/organic_facts/principles/ pdfs/IFOAM_FS_Principles_for Website.pdf, cited 5 December 2007

Jannink J-L, Bink MCAM, Jansen RC (2001) Using complex plant pedigrees to map valuable genes. Trends Plant Sci 6:337-342

Kapulnik Y, Okon Y, Henis Y (1987) Yield response of spring wheat cultivars (Triticum aestivum and T. turgidum) to inoculation with Azospirillum Brasiliense under field conditions. Biol Fertil Soils 4:27-35

Kempf H (2002) Weizenzüchtung für den ökologischen Landbau-Züchtung und Zulassung der Sorte Ökostar in Deutschland. Bericht über die Arbeitstagung 2002 der Vereinigung der Pflanzenzüchter und Saatgutkaufleute Österreichs gehalten vom 26-28 November 2002, BAL Gumpenstein

Kichey T, Hirel B, Heumez E, Dubois F, Le Gouis J (2007) Wheat genetic variability for post-anthesis nitrogen absorption and remobilisation revealed by $15 \mathrm{~N}$ labelling and correlations with agronomic traits and nitrogen physiological markers. Field Crops Res 102:22-32

Kirigwi FM, van Ginkel M, Trethowan R, Sears RG, Rajaram S, Paulsen GM (2004) Evaluation of selection strategies for wheat adaptation across water regimes. Euphytica 135:361-371

Kleijer G, Schwaerzel R (2006) Backqualität von Winterweizen in Bio- und Extenso-Zulassungsprüfungen. Agrar Forschung 13:56-61

Koebner RMD (2004) Marker assisted selection in the cereals: the dream and the reality. In: Gupta PK, Varshney RK (eds) Cereal genomics. Kluwer Academic Publishers, Dordrecht, The Netherlands, pp 317-330. ISBN 1-40202358-8

Kovács G (2006) Einkorn as a source for functional food production. Biokultúra 18:9-11

Kovács G, Szabó TA (2006) Genetic study and organic breeding of einkorn. In: Bedő Z, Kovács G (eds) Organic breeding and farming of cereals. Agroinform Publishing House, Budapest, Hungary, pp 73-78

Kunz P (2007) Jarhesbericht 2006, http://www.peter-kunz.ch, cited 10 December 2007

Kuzyakov Y (2002) Review: factors affecting rhizosphere priming effects. J Plant Nutr Soil Sci 165(4):382-396 
Lammerts van Bueren ET, Struik PC (2004) The consequences of the concept of naturalness for organic plant breeding and propagation. NJAS-Wagen J Life Sci 52:85-95

Lammerts van Bueren ET, Struik PC, Jacobsen E (2002) Ecological aspects in organic farming and its consequences for an organic crop ideotype. Neth J Agric Sci 50:1-26

Lammerts van Bueren ET, Struik PC, Tiemens-Hulscher M, Jacobsen E (2003) The concepts of intrinsic value and integrity of plants in organic plant breeding and propagation. Crop Sci 43:1922-1929

Lammerts van Bueren ET, van Soest LJM, de Groot EC, Boukema IW, Osman AM (2005a) Broadening the genetic base of onion to develop better-adapted varieties for organic farming systems. Euphytica 146:125-132

Lammerts van Bueren ET, Goldringer I, Østergård H (eds) (2005b) Proceedings of the COST SUSVAR/ECO-PB workshop on organic plant breeding strategies and the use of molecular markers, 17-19 January 2005, Driebergen, The Netherlands. Louis Bolk Institute, Driebergen, The Netherlands

Lammerts van Bueren ET, Verhoog H, Tiemens-Hulscher M, Struik PC, Haring MA (2007) Organic agriculture requires process rather than product evaluation of novel breeding techniques. NJAS Wagen J Life Sci 54:401-412

Láng L (2006) Improvement of protein content and adaptation of winter barley, triticale and spelt for organic farming. In: Bedő Z, Kovács G (eds) Organic breeding and farming of cereals. Agroinform Publishing House, Budapest, Hungary, pp 88-92

Laperche A, Devienne-Barret F, Maury O, Legouis J, Ney B (2006) A simplified conceptual model of carbon/nitrogen functioning for QTL analysis of winter wheat adaptation to nitrogen deficiency. Theor Appl Genet 113:1131-1146

Le Gouis J, Béghin D, Heumez E, Pluchard P (2000) Genetic differences for nitrogen uptake and nitrogen utilisation efficiencies in winter wheat. Eur J Agron 12:163-173

Legzdina L, Kokare A, Lammerts van Bueren ET (2007) Genotype and environment interaction of various spring barley genotypes in Organic and conventional growing conditions. In: Lammerts van Bueren ET, Goldringer I, Scholten $\mathrm{O}$, Østergård $\mathrm{H}$ (eds) Plant breeding for organic and sustainable, low-input agriculture: dealing with genotype $\times$ environment interactions. Book of abstracts of the Eucarpia symposium of working group organic plant breeding 7-9 November 2007, Wageningen, The Netherlands

Lemerle D, Verbeek B, Cousens RD, Coombes NE (1996) The potential for selecting wheat varieties strongly competitive against weeds. Weed Res 36:505-513

Lemerle D, Verbeek B, Orchard B (2001a) Ranking the ability of wheat varieties to compete with Lolium rigidum. Weed Res 41:197-209

Lemerle D, Gill GS, Murphy CE, Walker SR, Cousens RD, Mokhtari S, Peltzer SJ, Coleman R, Luckett DJ (2001b) Genetic improvement and agronomy for enhance wheat competitiveness with weeds. Aust J Agric Res 52:527548

Lemerle D, Cousens GS, Gill SJ, Peltzer M, Moerkerk CE, Murphy D, Collins D, Cullis BR (2004) Reliability of higher seeding rates of wheat for increased competitiveness with weeds in low rainfall environments. J Agric Sci 142:395-409

Letourneau D, Van Bruggen A (2006) Crop protection in organic agriculture. In: Kristiansen P, Taji A, Reganold J (eds) Advances in organic agriculture. CSIRO Publishing, Australia

Löschenberger F, Fleck A, Grausgruber G, Hetzendorfer H, Hof G, Lafferty J, Marn M, Neumayer A, Pfaffinger G, Birschitzky J (2008) Breeding for organic agriculture the example of winter wheat in Austria. Euphytica. doi:10.1007/s10681-008-9709-2

Lu MQ, O’Brien L, Stuart IM (1999) Barley malting quality and yield relationships and the effect on yield distribution of selection for malting quality. Aust J Agric Res 51:247258

Mäder P, Fliessbach D, Dubois D, Gunst L, Fried P, Niggli U (2002) Soil fertility and biodiversity in organic farming. Science 296:1694-1697

Manske GGB, Lüttger AB, Behl RK, Vlek PLG (1995) Nutrient efficiency based on VA Mycorrhizae (VAM) and total root length of wheat cultivars grown in India. Angew Botanik 69:108-110

Mason HE, Spaner D (2006) Competitive ability of wheat in conventional and organic management systems: a review of the literature. Can J Plant Sci 86:333-343

Mesterhazy A (1995) Types and components of resistance to Fusarium head blight of wheat. Plant Breed 114:377-386

Mitchell AE, Chassy AW (2004) Nutritional quality and organic agriculture. The Soy Connection 12:3-5

Molina Cano JL, Francesch M, Perez Vendrell AM, Ramo T, Voltas J, Brufau J (1997) Genetic and environmental variation in malting and feed quality of barley. Crop Sci 25:37-47

Morris ML, Bellon MR (2004) Participatory plant breeding research: opportunities and challenges for the international crop improvement system. Euphytica 136:21-35

Murphy K, Lammer D, Lyon S, Carter B, Jones SS (2005) Breeding for organic and low-input farming systems: an evolutionary-participatory breeding method for inbred cereal grains. Renew Agric Food Syst 20:48-55

Murphy KM, Campbell KG, Lyon SR, Jones SS (2007) Evidence of varietal adaptation to organic farming systems. Field Crops Res 102:172-177

Murphy KM, Reeves PG, Jones SS (2008) Relationship between yield and mineral nutrient concentrations in historical and modern spring wheat cultivars. Euphytica. doi:10.1007/s10681-008-9681-x

Negri V, Becker H, Onnela J, Sartori A, Strajeru S, Laliberté B (2000) A first inventory of on-farm conservation and management activities in Europe including examples of formal and informal sector cooperation. In: Laliberté B, Maggioni L, Maxted N, Negri V (eds) ECP/GR in situ and on-farm conservation network. International Plant Genetic Resources Institute, Rome, Italy

Oberforster M (2006) Ist die Sortenzulassungsprüfung biogerecht? Österreichische Fachtagung für biologische Landwirtschaft, 21-22 März 2006, Höhere Bundeslehrund Forschungsanstalt für Landwirtschaft RaumbergGumpenstein, Irdning, Austria

Oberforster M, Plakolm G, Söllinger J, Werteker M (2000) Are descriptions of conventional variety testing suitable for 
organic farming? IFOAM 2000-the world grows organic. In: Alföldi T, Lockeretz W, Niggli U (eds) Proceedings of the 13th international IFOAM scientific conference 28-31 August 2000, Basel, Switzerland. Vdf Hochschulverlag AG an der ETH Zürich

Oehl F, Oberson A, Tagmann HU, Besson JM, Dubois D, Mäder P, Roth HR, Frossard E (2002) Phosphorus budget and phosphorus availability in soils under organic and conventional farming. Nutr Cycl Agroecosyst 62:25-35

Ogushi K, Lim P, Barr AR, Takahashi S, Asakura T, Ito K (2002) Japanese barley meets Australia: quality performance of malting barley grown in different countries. $\mathrm{J}$ Inst Brew 108:303-309

Olofsdotter M, Jensen LB, Coutois (2002) Improving crop competitive ability using allelopathy-and example from rice. Plant Breeding 121:1-9

Østergård H, Kristensen K, Jensen JW (2005) Stability of variety mixtures of spring barley. In: Lammerts van $\mathrm{Bu}-$ eren ET, Goldringer I, Østergård $\mathrm{H}$ (eds) Proceedings of the COST SUSVAR/ECO-PB workshop on organic plant breeding strategies and the use of molecular markers, 1719 January 2005, Driebergen, The Netherlands. Louis Bolk Institute, Driebergen, The Netherlands

Østergård H, Kristensen K, Hovmøller M, Willas J (2006) Genetic potential for grain yield in spring barley varieties and variety mixtures in variable organic environments. In: Andreasen CB, Elsgaard L, Sørensen LS, Hansen G (eds) Organic farming and european rural development. Proceedings of the European joint organic congress, 30 and 31 May 2006, Odense, Denmark. Danish Research Centre for Organic Food and Farming (DARCOF), Tjele, Denmark

Padulosi S, Hodgkin T, Williams JT, Haq N (2002) Underutilized crops: trends challenges and opportunities in the 21st century. In: Engels JMM, Rao VR, Brown AHD, Jackson MT (eds) Managing plant genetic diversity. CABI International, Wallingford, UK

Paillard S, Goldringer I, Enjalbert J, Doussinault G, de Vallavieille-Pope C, Brabant P (2000a) Evolution of resistance against powdery mildew in winter wheat populations conducted under dynamic management. I. Is specific seedling resistance selected? Theor Appl Genet 101:449-456

Paillard S, Goldringer I, Enjalbert J, Trottet M, David J, de Vallavieille-Pope C, Brabant P (2000b) Evolution of resistance against powdery mildew in winter wheat populations conducted under dynamic management. II. Adult resistance. Theor Appl Genet 101:457-462

Panga XP, Leteya J (2000) Challenge of timing nitrogen availability to crop nitrogen requirements. Soil Sci Soc Am J 64:247-253

Papakosta DK (1994) Analysis of wheat cultivar differences in grain yield, grain nitrogen yield and nitrogen utilization efficiency. J Agron Crop Sci 172:305-316

Pester TA, Burnside OC, Orf JH (1999) Increasing crop competitiveness to weeds through crop breeding. J Crop Prod 2:59-72

Phillips SL, Wolfe MS (2005) Evolutionary plant breeding for low-input systems. J Agric Sci 143:245-254

Phillips SL, Shaw M, Wolfe MS (2005) The effect of potato variety mixtures on epidemics of late blight in relation to plot size and level of resistance. Ann Appl Biol 147:245252

Podlich DW, Winkler CR, Cooper M (2004) Mapping as you go: an effective approach for marker- assisted selection of complex traits. Crop Sci 44:1560-1571

Pommer G (1990) Accumulation and translocation of nitrogen in cultivars of wheat with different demands for nutrition. In: Bassam El et al (eds) Genetic aspects of plant nutrition. Kluwer Academic Publishers, Dordrecht, The Netherlands

Przulj N, Momcilovich V (2001a) Genetic variation for dry matter and nitrogen accumulation and translocation in two-rowed spring barley I. Dry matter translocation. Eur J Agron 15:241-254

Przulj N, Momcilovich V (2001b) Genetic variation for dry matter and nitrogen accumulation and translocation in two-rowed spring barley-II. Nitrogen translocation. Eur J Agron 15:255-265

Przystalski M, Osman AM, Thiemt EM, Rolland B, Ericson L, Østergård H, Levy L, Wolfe MS, Büchse A, Piepho H-P, Krajewski P (2008) Do cereal varieties rank differently in organic and non-organic cropping systems? Euphytica. doi:10.1007/s10681-008-9715-4

Rakszegi M, Láng L, Bedő Z (2006) Development of wheat genotypes for organic farming using classical and molecular marker assisted selection techniques (ökológiai gazdálkodásra alkalmas búza genotípusok szelekciója molekulárias és hagyományos nemesítéssel). In: Bedő Z, Kovács G (eds) Organic breeding and farming of cereals. Agroinform Publishing House, Budapest 79-85, Hungarian

Rastoin JL (2006) Vers de nouveaux modèles d'organisation des systèmes agroalimentaires? Analyse stratégique. Presented at the Research Seminar "Produits de terroir, filière qualité et développement", Montpellier, MSH-SH, 2006, 22th of June. Available via The Montpellier Social Sciences and Humantities Reseach Institute. http://www.msh-m.fr/ IMG/nouveaux_modeles_d_organisation_du_systeme_ agroalimentaire.pdf, cited 6 December 2007

Rebetzke GJ, Richards RA (1999) Genetic improvement of early vigour in wheat. Aust J Agric Res 50:291-301

Saulescu NN, Ittu G, Mustatea P, Simion G (2005) Improved nitrogen response as an objective in wheat breeding. Romanian Agric Res 22:1-4

Schwaerzel R, Levy L, Menzi M, Anders M, Winzeler H, Dörnte J (2006) Winterweizensorten im biologischen und extensiven Anbau. Agrar Forschung 13:68-73

Sinebo W, Gretzmacher R, Edelbauer A (2002) Environment o selection for grain yield in low fertilizer input barley. Field Crops Res 74:151-162

Spanakakis A, Röbbelen G (1990) Selektion auf erhöhtes Stickstoffaneignungsvermögen in einem WinterweizenZuchtprogramm. Bericht über die Arbeitstagung 1990 der Arbeitsgemeinschaft der Saatzuchtleiter, 20-22 November 1990 in Gumpenstein. Verlag und Druck der Bundesanstalt für alpenländische Landwirtschaft Gumpenstein, Austria

Sperling L, Ashby JA, Smith ME, Weltzien E, McGuire S (2001) A framework for analyzing participatory plant breeding approaches and results. Euphytica 122: 439-450 
Steele KA, Virk DS, Prasad SC, Kumar R, Singh DN, Gangwar JS, Witcombe JR (2004) Combining PPB and markerassisted selection: strategies and experiences with rice. Crop Sci 44:1560-1571

Suneson CA (1960) Genetic diversity-a protection against plant diseases and insects. Agron J 52:319-321

Tarakanovas P, Ruzgas V (2006) Additive main effect and multiplicative interaction analysis of grain yield of wheat varieties in Luthuania. Agron Res 4:91-98

Tilman D, Reich PB, Knops JMH (2006) Biodiversity and ecosystem stability in a decade-long grassland experiment. Nature 441:629-632

Udall JA, Wendel JF (2006) Polyploidy and crop improvement. Crop Sci 46:3-14

Veisz O (2006) Testing the productivity and quality of oat under organic farming conditions. In: Bedő Z, Kovács G (eds) Organic breeding and farming of cereals. Agroinform Publishing House, Budapest, Hungary, pp 93-96

Verhoog H, Matze M, Lammerts van Bueren ET, Baars T (2003) The role of the concept of the natural (naturalness) in organic farming. J Agric Environ Ethics 16:29-49

Wächter R, Waldow F, Müller K-J, Spieß H, Heyden B, Furth U, Frahm J, Weng W, Miedaner T, Stephan D, Koch E (2007) Charakterisierung der Resistenz von Winterweizensorten und-zuchtlinien gegenüber Steinbrand (Tilletia tritici) und Zwergsteinbrand (T. controversa). Nachrichtenbl Deut Pflanzenschutzd 59:30-39
Werner K, Friedt W, Ordon F (2005) Strategies for pyramiding resistance genes against the barley yellow mosaic virus complex (BaMMV, BaYMV, BaYMV-2). Mol Breed 16:45-55

Wiesler F, Horst WJ (1994) Root growth and nitrate utilization of maize cultivars under field conditions. Plant Soil 163:267-277

Wilbois K-P, Spieß H, Vogt-Kaute W, Jahn M, Waldow F, Koch E, Wächter R, Müller K-J (2005) Control of seedborne diseases: strategies for organic farming. In: $\mathrm{He} ß \mathrm{~J}$, Rahmann G (eds) Ende der Nische-Beiträge zur 8 . Wissenschaftstagung Ökologischer Landbau, Kassel, 1-4 März 2005. Kassel University Press GmbH, Kassel, Germany

Witcombe JR, Virck DS (2001) Number of crosses and population size for participatory and classical plant breeding. Euphytica 122:451-462

Wolfe MS (1985) The current status and prospects of multiline cultivars and variety mixtures for disease control. Ann Rev Phytopathol 23:251-273

Wu H, Pratley J, Lemerle D, Haig T (2000) Evaluation of seedling allelopathy in 453 wheat (Triticum aestivum) accessions against annual ryegrass (Lolium rigidum) by the time equal compartment agar method. Aust J Agric Res 51:937-944 